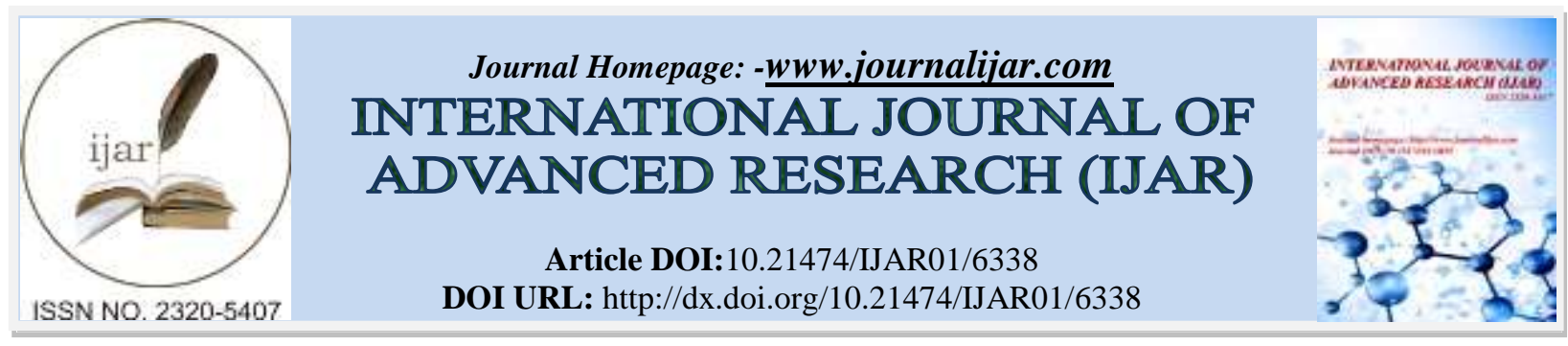

RESEARCH ARTICLE

\title{
PERFORMANCE EVALUATION OF SORGHUM VARIETIES IN POTHWAR AREAS OF PAKISTAN.
}

\section{Muhammad Imran Khan $^{1}$, Muhammad Zeeshan ${ }^{1}$, Waheed Arshad ${ }^{1}$, Shiraz Ali $^{1}$, Ali Nawaz ${ }^{1}$, AminaBatool ${ }^{1}$ and Muhammad Tariq ${ }^{2}$.}

1. Barani Agricultural Research Station, Fatehjang, Attock, Pakistan.

2. Barani Agricultural Research Institute, Chakwal, Pakistan.

\section{Manuscript Info}

Manuscript History

Received: 18 November 2017

Final Accepted: 20 December 2017

Published: January 2018

Key words:-

Sorghum, Varietal variation, grain yield, fodder yield and yield traits.

\section{Abstract}

Twenty sorghum entries were screened for grain and other associated characters at the Barani Agricultural Research Station, Fatehjang, Attock, Pakistan in 2017. These sorghum genotypes showed different attributes against different traits. The results revealed that greater flag leaf area, stem diameter, number of leaves/ plant and plant height was observed in FJSS-09, FJSS-23 and Higari genotypes. Among these entries, higher grain and fodder yield was noted in FJSS-09 (3820 $\mathrm{kg} / \mathrm{ha} \& 23456 \mathrm{~kg} / \mathrm{ha}$ ) and FJSS-23 (3643 kg/ha \& $22576 \mathrm{~kg} / \mathrm{ha})$. The genotype PARC-SS-1 exhibited earliness as it took 111 days to mature while PGRI-191 was found late maturing entry (124 days).

Copy Right, IJAR, 2018,. All rights reserved.

\section{Introduction:-}

Sorghum (Sorghum bicolor L.) is a major kharif and cereal crop in arid and semi-arid areas of the world. It is also a predominant crop of rain fed areas of Pakistan and is grown both for fodder and grain purpose. It has been estimated that need for forage crops will increase two to three folds in Asian countries upto 2050 (Devendra and Leng, 2011). Sorghum has potential of adoption to adverse climatic conditions and with the introduction of early maturing and high yielding hybrids, the crop has gained importance in the irrigated areas as well. Sorghum fodder possesses oxalic acid and prussic acid. It produces a tonnage of dry matter having digestible nutrients (50\%), crude protein (8 $\%$ ), fat (2.5\%) and nitrogen free extracts (45\%) (Azam et al., 2010). It can be used fresh as well as can be stored in form of silage and hay for future use. Its grains contain about $10-12 \%$ protein, $03 \%$ fat and $70 \%$ carbohydrates, therefore, it can replace other grains in the feeding program for dairy cattle and poultry (Ullahet al ., 2007). Sorghum is also a good subtract for ethanol production which can be added to fuel for saving precious foreign exchange (Reddy et al., 2005). Its grain has high level of iron $(>70 \mathrm{ppm})$ and zinc $(>50 \mathrm{ppm})$, which can reduce micronutrient malnutrition globally. Sorghum is an important summer annual grass and ranks fifth among cereal crops in the world. Sorghum plant is unique in stature and can grow in adverse environments. It has a very large and extensive tap root system that enables it to obtain water and nutrients from soil depth of over five feet. In another study nine sorghum hybrids and 17 varieties were evaluated at 47 locations and hybrids showed higher yields than varieties (Alagarsamy, 1993). Zahid and Bhatti (1994) also reported that sorghum hybrids, having more numbers of leaves/plant and higher leaf area, produced maximum green and dry fodder yields. Moreover, it fulfills more than $50 \%$ requirement of the rain fed region of the country. The production of Barley, Jowar, Rapeseed \&Mastard and Tobacco has witnessed decrease in production during 2016-17 by posting negative growth of 9.8 percent 7.5 percent, 3.2 percent and 2.6 percent, respectively. Average area and production of sorghum was 257 (000 ha) and 149 (000 tones) during 2016-17 (Anonymous, 2016-17). In Pakistan, there are two critical durations for fodder scarcity, first in May-June during summer and second in October-November during winter. Due to stay green trait, sorghum 
improvement for yield and quality characters can greatly reduce the risk of inadequate forage production during summer. Based on these observations, the present study was conducted to evaluate sorghum genotypes potential for their grain and fodder yields and other related traits. The interaction between genotype and environment has been an important factor while selecting the variety for the area (Nawaz et al., 2004).

\section{Material and Methods:-}

The present study comprised of twenty sorghum genotypes that were evaluated at Barani Agricultural Research Station, Fatehjang, Attock, Pakistan in 2017. The trial was sown in a randomized complete block design with three replications; each consisted of $45 \mathrm{~cm}$ apart and 5 meter long four rows. All other agronomic practices were kept uniform for all the treatments. Ten plants were selected randomly from central 2-rows of each plot for data recording on days to $50 \%$ flowering, days to maturity, plant height, stalk and grain yield. Grain yield was adjusted to $15 \%$ grain moisture using the formula as prescribed by Taranet al. (1998). Grain and stalk yields were recorded and then converted to $\mathrm{kg}$ per hectare. The data were analyzed statistically (Steel et al., 1997) and means were compared using least significant difference test through MSTATC computer software (MSTATC, 1991). Detail of sorghum genotypes is given in table 1 ;

Table 1:-List of sorghum genotypes with source/ location

\begin{tabular}{|l|l|l|}
\hline Sr. No. & Name of Sorghum Genotypes & Source/ Location \\
\hline 01 & Chakwal Sorghum & Barani Agricultural Research Institute, Chakwal \\
\hline 02 & PARC-SS-1 & National Agricultural Research Centre, Islamabad \\
\hline 03 & PARC-SS-2 & National Agricultural Research Centre, Islamabad \\
\hline 04 & PARC-SV-10 & National Agricultural Research Centre, Islamabad \\
\hline 05 & Johar & National Agricultural Research Centre, Islamabad \\
\hline 06 & PGRI-79 & National Agricultural Research Centre, Islamabad \\
\hline 07 & PGRI-141 & National Agricultural Research Centre, Islamabad \\
\hline 08 & PGRI-191 & National Agricultural Research Centre, Islamabad \\
\hline 09 & Rari-S-4 & Regional Agricultural Research Institute, Bahawalpur \\
\hline 10 & YSS-09 & Maize and Millet Research Institute, YousafWala \\
\hline 11 & YSS-13 & Maize and Millet Research Institute, YousafWala \\
\hline 12 & YSS-98 & Maize and Millet Research Institute, YousafWala \\
\hline 13 & FJSS-02 & Barani Agricultural Research Station, Fatehjang \\
\hline 14 & FJSS-05 & Barani Agricultural Research Station, Fatehjang \\
\hline 15 & FJSS-09 & Barani Agricultural Research Station, Fatehjang \\
\hline 16 & FJSS-23 & Barani Agricultural Research Station, Fatehjang \\
\hline 17 & FRI-07 & Fodder Research Institute, Sargoda \\
\hline 18 & SGD-011-2 & Fodder Research Institute, Sargoda \\
\hline 19 & JS-263 & Fodder Research Institute, Sargoda \\
\hline 20 & Higari & Fodder Research Institute, Sargoda \\
\hline
\end{tabular}

Table 2:-List of various traits as exhibitted by Sorghum varieties/advance lines

\begin{tabular}{|l|l|l|l|l|l|l|l|l|}
\hline varieties & $\begin{array}{l}\text { Flag leaf } \\
\text { area } \\
\left(\mathbf{c m}^{\mathbf{2}}\right)\end{array}$ & $\begin{array}{l}\text { Stem } \\
\text { diameter } \\
(\mathbf{c m})\end{array}$ & $\begin{array}{l}\text { No. of } \\
\text { leaves/ } \\
\text { plant }\end{array}$ & $\begin{array}{l}\text { Grain } \\
\text { yield } \\
(\mathbf{k g} / \mathbf{h a})\end{array}$ & $\begin{array}{l}\text { Fodder } \\
\text { yield } \\
\text { (kg/ha) }\end{array}$ & $\begin{array}{l}\text { Plant } \\
\text { height } \\
(\mathbf{c m})\end{array}$ & $\begin{array}{l}\text { Days to } \\
\mathbf{5 0 \%} \\
\text { flowering }\end{array}$ & $\begin{array}{l}\text { Days to } \\
\text { maturity }\end{array}$ \\
\hline FJSS-09 & $32 \mathrm{a}$ & $17.36 \mathrm{a}$ & $13 \mathrm{a}$ & $3820 \mathrm{a}$ & $23456 \mathrm{a}$ & $230 \mathrm{a}$ & $74 \mathrm{bc}$ & $118 \mathrm{bc}$ \\
\hline FJSS-23 & $28 \mathrm{a}$ & $15.52 \mathrm{~b}$ & $12 \mathrm{~b}$ & $3643 \mathrm{a}$ & $22578 \mathrm{a}$ & $211 \mathrm{~b}$ & $71 \mathrm{bc}$ & $115 \mathrm{~cd}$ \\
\hline PARC-SS-1 & $24 \mathrm{~b}$ & $12.97 \mathrm{~d}$ & $12 \mathrm{~b}$ & $3570 \mathrm{~b}$ & $21340 \mathrm{bc}$ & $192 \mathrm{c}$ & $67 \mathrm{~d}$ & $111 \mathrm{de}$ \\
\hline Higari & $25 \mathrm{~b}$ & $16.41 \mathrm{a}$ & $13 \mathrm{a}$ & $3512 \mathrm{~b}$ & $22690 \mathrm{~b}$ & $178 \mathrm{~d}$ & $72 \mathrm{bc}$ & $116 \mathrm{c}$ \\
\hline Ch. Sorghum & $21 \mathrm{bc}$ & $12.04 \mathrm{~d}$ & $11 \mathrm{c}$ & $3423 \mathrm{~b}$ & $23780 \mathrm{a}$ & $202 \mathrm{bc}$ & $69 \mathrm{c}$ & $113 \mathrm{~d}$ \\
\hline Rari-S-4 & $18 \mathrm{c}$ & $14.33 \mathrm{c}$ & $11 \mathrm{c}$ & $3354 \mathrm{~b}$ & $21467 \mathrm{bc}$ & $206 \mathrm{bc}$ & $72 \mathrm{bc}$ & $116 \mathrm{c}$ \\
\hline YSS-09 & $25 \mathrm{~b}$ & $13.01 \mathrm{~cd}$ & $12 \mathrm{~b}$ & $3212 \mathrm{bc}$ & $20342 \mathrm{c}$ & $195 \mathrm{c}$ & $74 \mathrm{bc}$ & $118 \mathrm{bc}$ \\
\hline FRI-07 & $23 \mathrm{bc}$ & $14.49 \mathrm{c}$ & $13 \mathrm{a}$ & $3056 \mathrm{c}$ & $21324 \mathrm{bc}$ & $172 \mathrm{~d}$ & $79 \mathrm{a}$ & $123 \mathrm{a}$ \\
\hline SGD-011-2 & $27 \mathrm{a}$ & $11.21 \mathrm{de}$ & $11 \mathrm{c}$ & $2843 \mathrm{c}$ & $23675 \mathrm{a}$ & $201 \mathrm{bc}$ & $75 \mathrm{bc}$ & $119 \mathrm{bc}$ \\
\hline YSS-13 & $15 \mathrm{~d}$ & $10.41 \mathrm{e}$ & $12 \mathrm{~b}$ & $2713 \mathrm{~cd}$ & $22234 \mathrm{~b}$ & $169 \mathrm{~d}$ & $71 \mathrm{bc}$ & $115 \mathrm{~cd}$ \\
\hline YSS-98 & $22 \mathrm{bc}$ & $12.22 \mathrm{~d}$ & $11 \mathrm{c}$ & $2604 \mathrm{~cd}$ & $21765 \mathrm{bc}$ & $157 \mathrm{e}$ & $77 \mathrm{~b}$ & $121 \mathrm{~b}$ \\
\hline
\end{tabular}




\begin{tabular}{|l|l|l|l|l|l|l|l|l|}
\hline FJSS-02 & $19 \mathrm{c}$ & $14.15 \mathrm{c}$ & $13 \mathrm{a}$ & $2534 \mathrm{~d}$ & $20780 \mathrm{c}$ & $200 \mathrm{bc}$ & $72 \mathrm{bc}$ & $116 \mathrm{bc}$ \\
\hline FJSS-05 & $16 \mathrm{~d}$ & $8.79 \mathrm{f}$ & $10 \mathrm{~d}$ & $2430 \mathrm{~d}$ & $19342 \mathrm{~cd}$ & $168 \mathrm{~d}$ & $70 \mathrm{c}$ & $114 \mathrm{~cd}$ \\
\hline JS-263 & $22 \mathrm{bc}$ & $9.32 \mathrm{f}$ & $11 \mathrm{c}$ & $2218 \mathrm{de}$ & $21546 \mathrm{bc}$ & $171 \mathrm{~d}$ & $72 \mathrm{bc}$ & $116 \mathrm{c}$ \\
\hline PARC-SS-2 & $26 \mathrm{~b}$ & $14.12 \mathrm{c}$ & $12 \mathrm{~b}$ & $2156 \mathrm{de}$ & $23820 \mathrm{a}$ & $195 \mathrm{c}$ & $74 \mathrm{bc}$ & $118 \mathrm{bc}$ \\
\hline PARC-SV-10 & $17 \mathrm{~d}$ & $10.64 \mathrm{e}$ & $13 \mathrm{a}$ & $2067 \mathrm{e}$ & $21640 \mathrm{bc}$ & $203 \mathrm{bc}$ & $71 \mathrm{bc}$ & $115 \mathrm{~cd}$ \\
\hline Johar & $21 \mathrm{bc}$ & $12.20 \mathrm{~d}$ & $12 \mathrm{~b}$ & $1845 \mathrm{f}$ & $22910 \mathrm{a}$ & $157 \mathrm{e}$ & $69 \mathrm{c}$ & $113 \mathrm{~d}$ \\
\hline PGRI-79 & $16 \mathrm{~d}$ & $13.34 \mathrm{~cd}$ & $11 \mathrm{c}$ & $1723 \mathrm{f}$ & $20623 \mathrm{c}$ & $176 \mathrm{~d}$ & $73 \mathrm{bc}$ & $117 \mathrm{c}$ \\
\hline PGRI-141 & $19 \mathrm{c}$ & $12.41 \mathrm{~d}$ & $13 \mathrm{a}$ & $1645 \mathrm{f}$ & $19358 \mathrm{~cd}$ & $168 \mathrm{~d}$ & $78 \mathrm{a}$ & $122 \mathrm{a}$ \\
\hline PGRI-191 & $24 \mathrm{~b}$ & $14.71 \mathrm{c}$ & $11 \mathrm{c}$ & $1578 \mathrm{~g}$ & $20645 \mathrm{c}$ & $163 \mathrm{~d}$ & $80 \mathrm{a}$ & $124 \mathrm{a}$ \\
\hline LSD 0.05 & $\mathbf{5 . 1 2}$ & $\mathbf{1 . 7 6}$ & $\mathbf{0 . 8 7}$ & $\mathbf{1 8 3 . 1 1}$ & $\mathbf{1 5 6 7}$ & $\mathbf{1 5 . 2 6}$ & $\mathbf{2 . 1 1}$ & $\mathbf{2 . 3 3}$ \\
\hline
\end{tabular}

\section{Results and Discuession:-}

Flag leaf area $\left(\mathrm{cm}^{2}\right)$ :-

The data in table 2 showed that sorghum genotypes differ significantly for flag leaf area. The highest area was observed in FJSS-09 $(32 \mathrm{~cm})$ and FJSS-23 $(28 \mathrm{~cm})$ followed by Higari $(25 \mathrm{~cm})$, while lowest flag leaf area was noted in PGRI-79 (16 cm). The comparison made by Naeemet al., (2002) and Kainthet al., (2004) also reported significant variations among sorghum genotypes for leaf area per plant.

\section{Stem diameter $(\mathbf{c m})$ :-}

The data revealed that sorghum genotypes showed significant variations for stem diameter. The genotype FJSS-09 showed highest stem diameter $(17.36 \mathrm{~cm})$ and Higari $(16.41 \mathrm{~cm})$ followed by FJSS-23 $(15.52 \mathrm{~cm})$ whereas lowest observation was found in FJSS-05 $(8.79 \mathrm{~cm})$. Our findings for stem diameter have also been confirmed by the findings of Naeemet al., (2002) where a range of stem diameter was observed for cultivars.

\section{No. of leaves/ plant:-}

Varieties also differed significantly in no. of leaves per plant (Table-2). The highest no. of leaves/ plant was obtained from varieties FJSS-09, Higari, FRI-07 and PARC-SV-10 i.e. (13) followed by FJSS-23 and PARC-SS-1 (12).The lowest no. of leaves/ plant was observed in variety Rari-S-4 and Chakwal sorghum (11).

\section{Days to $50 \%$ flowering:-}

The data exhibited that sorghum genotypes differ significantly in days to $50 \%$ flowering. Sorghum variety PGRI191 and PGRI-141took maximum days (80 and 78) to 50\% flowering than varieties ch. sorghum and PARC-SS1taking 69 and 67 days to $50 \%$ flowering and proved as early maturing. Similar study was also reported by NazirHussianet al., 2011 and Alagarsamy (1993).

\section{Days to maturity:-}

The trait days to maturity is usually based on the flowering pattern of genotypes. Days to maturity was significantly affected by sorghum varieties (Table-2). Sorghum varieties PARC ch. sorghum and PARC-SS-1 showed earliness by taking 111 and 113 days to maturity respectively, followed by FJSS-23 (115 days) and Rari-S-4 (116). Genotype PGRI-191 and PGRI-141 were found late, which matured in 124 and 122 days respectively.

\section{Plant height (cm):-}

A perusal of data inTable-2 indicated that maximum plant height $(230 \mathrm{~cm})$ was recorded in FJSS-09 and FJSS-23 $(211 \mathrm{~cm})$, which was statistically at par with Rari-S-4 $(206 \mathrm{~cm})$, PARC-SV-10 (203) and Ch. Sorghum $(202 \mathrm{~cm})$. While genotype YSS-98 and Johar were found short statured (157 cm). Olakajo and Iken (2001) also reported significant variations in plant height among various maize varieties. The earlier studies conducted by Nabiet al., (2006) and Ayubet al., (2010) for sorghum cultivars also supported our findings for plant height.

\section{Grain yield (kg/ha):-}

The analysis of data indicated that sorghum varieties showed significant variations for grain yield. The highest grain yield was obtained from sorghum variety FJSS-09 and FJSS-23 (3820 kg/ ha \& $3643 \mathrm{~kg} / \mathrm{ha}$ ), which was statistically at par with PARC-SS-1 (3570 kg/ha) and Higari (3512 kg/ha). Lowest grain yield was observed in PGRI-191 (1578 $\mathrm{kg} / \mathrm{ha}$ ). Similar results were reported by Osmanzai (1994). 
Fodder yield (kg/ha):-

A perusal of data (Table-2) revealed that maximum fodder yield was noted in PARC-SS-2 $(23820 \mathrm{~kg} / \mathrm{ha}), \mathrm{ch}$. Sorghum (23780 kg/ha) and SGD-011-2 (23675 kg/ha). The lowest fodder yield was recorded in genotypes PGRI141 (19358 kg/ha) and FJSS-05 (19342kg/ha). Similar results were also reported by Mehmudet al., (2003). The significant variations among sorghum genotypes for dry matter production have already been reported in studies conducted by Yousefet al., (2009).

\section{Conclusion:-}

Based on following results, it was concluded that sorghum varieties differ significantly in their capability of producing higher grain and fodder yield in Potohar region of Pakistan. These results revealed that FJSS-09 and FJSS-23 gave maximum grain yield i.e. $3820 \mathrm{~kg} / \mathrm{ha} \& 3643 \mathrm{~kg} / \mathrm{ha}$, whereas maximum fodder yield was noted in PARC-SS-2 (23820 kg/ha), ch. Sorghum (23780 kg/ha) and SGD-011-2 (23675 kg/ha).

\section{References:-}

1. Alagarsamy, G. (1993): International sorghum and variety adaption trials. Cereal Program. ICRISAT. Annual Report; pp. 104-105.

2. Anonymous. (2017): Pakistan Economic Survey, 2016-17. Finance Division, Islamabad. pp: 25.

3. Ayub, M., Nadeem, M.A, Tahir, M, Ghafoor, A, Ahmed, Z and. Naeem, M. (2010): Comparitive studies on the growth, forage yield and quality of sorghum (Sorghum bicolor L.) varieties under irrigated conditions of Faisalabad. Pak. J. Life Soc. Sci., 8(2): 94-97.

4. Azam, M., Waraich, E.A., Pervaiz, A. and Nawaz, F. (2010): Response of a newly developed fodder (Sorghum bicolor L. monech) variety (F-9917) to NPK application. Pak. J. Life Soc. Sci. 8: 117-120.

5. Devendra, C., and Leng R.A (2011): Feed resources for animals in Asia: issues, strategies for use, intensification and integration for increased productivity. Asian-Aust. J. Anim. Sci. 24 : 303-321.

6. Kainth, R.A., Naeem M, Chohan, M.S.M. and. Khan A.H. (2004): Fodder yield potential of advanced lines of sorghum under irrigated conditions. J. Agric. Res. 42: 277-281.

7. Mehmud, K., Ahmad, L and Ayub, M. (2003): Effect of nitrogen and phosphorus on the fodder yield and quality of two sorghum (Sorghum bicolor L.) cultivars. Int. J. Agric. Biol. 5: 61 - 63.

8. MSTATC. (1991): MSTATC package, version 1. Michigan State Univ. USA.

9. Nabi, C.G., Riaz, M. and. Ahmed, G (2006): Comparison of some advanced lines of Sorghum bicolor L. Monechfor green fodder/dry matter yield and morpho economical parameters. J. Agric. Res. 44: 191-196.

10. Naeem, M., Chauhan, M.S.M., Khan, A.H. and. Salahudin, S. (2002): Evaluation of different varieties of sorghum for green fodder yield potential. Asian J. P1. Sci. 1: 142-143.

11. Nawaz, N., Razzaq, A., Ali, Z, Sarwar, G. and. Yousaf, M. (2004): Performance of different oat (Avena sativa L.) varieties under the agro-climatic conditions of Bahawalpur. Pak. Int. J. Agri. Biol. 6: 624-626.

12. Olakajo, S.A. and Iken, K.E. (2001): Yield performance and stability of some improved maize varieties. Moor. J. Agric. Res., 2: 21-24.

13. Osmanzai, M. (1994): Relative performance of sorghum hybrids and open pollinated cultivars under two soil moisture regimes. Intl. Sorghum and Millet Newslett., 35: 131.

14. Reddy, B.V.S., Ramesh, S., Reddy, P.S., Ramaiah, B., Salimath, P.M. and Kachapur, R. (2005): Sweet sorghum-A potential alternative raw material for bioethanol and bio-energy. Intl Sorghum MilletNewslett; 46:79-86.

15. Steel, R.G.D., Torrie, J.H. and Dicky, D.A. (1997): Principles and Procedures of Statistics, A Biometrical Approach . 3rd Ed. McGraw Hill, Inc. Book Co. N.Y. (USA.), pp. 352-358.

16. Taran, S.A., Kakar, M.S. and Bugti, R.A. (1998): Performance of maize varieties/hybrids under irrigated conditions of Balochistan. Sarhad J. Agric., 14:113-116.

17. Ullah, A., Khan, A.A., Nawab, K., Khan, A. and Islam, B. (2007): Growth characters and fodder production potential of sorghum varieties under irrigated conditions. Sarhad J Agric.,23: 265- 268.

18. Zahid, M.S. and Bhatti, M.B. (1994): Comparative study on fodder yields potential of different sorghum hybrids under rainfed conditions. Sarhad J Agric., 10:345-350.

19. Yousef, E., Carmi, A., Nikbachat M., Zenou, A. Umiel, N., and. Miron, J. (2009): Characteristics of tall versus short-type varieties of forage sorghum grown under two irrigation levels, for summer and subsequent fall harvests, and digestibility by sheep of their silages. Anim. Feed Sci. Tech., 152: 1-11. 